\title{
Restitution of Non-Physical Impact in Land Acquisition for Development in Public Interest
}

\author{
Donna Okthalia Setiabudhi* Toar Neman Palilingan Jeany Anita Kermite \\ Faculty of Law, Sam Ratulangi University, North Sulawesi, Indonesia
}

\begin{abstract}
The research aims to determine the arrangements of restitution for non-physical losses in the implementation of land acquisition for development in the public interest. The research is a normative-legal research with using statute and case approaches. The research was conducted in North Sulawesi Province, Indonesia. The results show that the arrangement of restitution for non-physical impacts in Land Acquisition Act is still very limited. It is caused by the lack of clarity regarding the authority to determine the loss of non-physical impacts, the mechanism for determining the loss, and the absence of a regulation regarding the criteria and indicators of nonphysical losses that can be valued. The limited arrangement of compensation for non-physical impacts in these laws causes the implementation of land acquisition related to non-physical losses does not show justice and protection of human rights. Non-physical losses in land acquisition need to be regulated clearly and firmly in terms of authority, mechanism and categories and indicators so that they can become a reference for implementing land acquisition, those who need land and land appraisers to provide legal certainty for them in taking decisions that will not cause any legal issues and harm the country.
\end{abstract}

Keywords: Acquisition; Land; Restitution; Public Interest

DOI: $10.7176 / \mathrm{EJBM} / 11-27-18$

Publication date:September $30^{\text {th }} 2019$

\section{Introduction}

National development is conducted as an effort to fulfill the mandate in the 1945 Constitution of the Republic of Indonesia. Basically, the responsibility for achieving this national goal is the responsibility of all components in the State includes the government, the private sector and Indonesian people. The development requires capital and one of the one is fixed capital such as land. ${ }^{1}$ In Indonesia, the right to land basically has got the main regulation that refers to Basic Agrarian Law (BAL). However, since the land is also part of the law of property and material law in general, the investigation of land rights is not enough simply by referring to BAL, but also considering the law of things as part of the property law in general. ${ }^{2}$

Recently, an effort to acquire land through the mechanism of land acquisition in the public interest as regulated through Act No. 2 of 2012 concerning Land Acquisition. Land acquisition for public interest is a manifestation of the social function of land. It is essentially one of the initial efforts for the government in providing services to the community. Land acquisition for public purposes aims to provide land for the implementation of development in order to improve the welfare of the nation, State and society while still ensuring the legal interests of the parties. ${ }^{3}$

The purpose of the law on the implementation of land acquisition for development in the public interest is done by promoting the principles of humanity, democracy and justice. Thus, the implementation of land acquisition must be able to meet the principles of humanity, democracy and most importantly the principle of justice for those involved in the land acquisition process. Restitution as Act No. 2 of 2012 is an appropriate and fair restitution to the party entitled to the land acquisition process. Non-physical losses include loss of work, field of business, income source, and other sources of income which have an impact on decreasing the level of person' welfare.

However, the current reality of land acquisition shows that problems occur specifically related to restitution. For the National Land Agency, restitution has been a focus for implementing land acquisition like physical restitution for land and objects on land, while non-physical restitution has not received much attention, therefore causing conflicts in the implementation of land acquisition, as it happening in Manado, North Sulawesi, Indonesia. The government program for the construction of toll road Manado-Bitung is not going well because the land rights holders assessing that the value of restitution is not in accordance with the wishes and losses.

So far, land acquisition is only focused on paying restitution for the physical value such as land, buildings and plants as well as objects on the land and has not paid attention to non-physical losses such as business, livelihood and environmental losses suffered by people who are around the area of the implementation of land

\footnotetext{
${ }^{1}$ Syah, M.I. (2015). Pembebasan Tanah Untuk Pembangunan Kepentingan Umum. Jakarta: Permata Aksara, p. 3

${ }^{2}$ Agustina, E. (2018). The Social Function of Land Rights in Indonesia: The Basic Agrarian Law and Customary Rights by the State. Journal of Legal, Ethical and Regulatory Issues, 21(SI): 1-8.

${ }^{3}$ Limbong, B. (2011). Pengadaan Tanah untuk Pembangunan. Jakarta: Margaretha Pustaka. p. 131
} 
acquisition in the public interest, thus it encourage the researcher in further studying the restitution for nonphysical impacts in land acquisition for public interest with the problem of how to regulate restitution for nonphysical losses in Indonesia and how the application of the provisions regarding restitution of non-physical impacts in the implementation of land acquisition for development in the public interest.

\section{Method of the Research}

The research was conducted in North Sulawesi Province. Infrastructure development becomes focus of government in North Sulawesi. The populations of research are government officials, the private sector and the community. The sampling technique was determined by purposive sampling. The data analysis was done through qualitative analysis.

\section{Reviewing the Non-Physical Losses Impact Reviewed from A Justice Theory}

Theories of Natural Law are known from the time of Socretes to Francois Geny by placing justice as the crown of law or referred to as "the search for justice". ${ }^{1}$ Various theories about justice and a just society show many attentions are given to the issue of justice. One theory of justice relating to rights and freedoms, opportunities for power, income and prosperity is the theory of John Rawls. Rawls is believed to be one of the people who gave considerable influence to the discourse on the values of justice to date. ${ }^{2}$

John Rows' theory of justice emphasizes 2 (two) principles of justice, it is often used as a reference by some experts, namely equal liberty principle and differences principle. Rawls argues that if there is a conflict, then equal liberty principle must be prioritized over other principles. The equal liberty principle must be prioritized over the difference's principle. ${ }^{3}$ Everyone has the same right to the most extensive and compatible basic freedoms with similar freedoms for others. Thus, the principle of justice is essentially talking about justice for the community or social justice, so the priority focus is the unfortunate community.

In the implementation of land acquisition consists of 5 (five) stages, including: First, inventory and identification of possession, ownership, use and utilization of land; Second, valuation of restitution; Third, deliberations on determining restitution; Fourth, restitution; and Fifth, the release of agency land. From the five stages, the stages related to valuation are the second stage, namely the valuation of restitution. The valuation of restitution in land acquisition is emphasized that the determination of the amount of restitution is done by the Chairman of the Land Acquisition Officer based on the results of the appraisal or public appraisal services as determined by the Chairman of the Land Acquisition Officer.

As a comparative study to the experience of land acquisition in other countries, ${ }^{4}$ it is done to eliminate imbalances. Land acquisition causes large-scale population displacement. Thus, a form of restitution is needed that minimizes displacement in the sense that the displaced person will always be in a position capable of buying alternative land. Basically, this becomes one of the souls of the Land Acquisition Acts which states that in land acquisition, the welfare of landowners must remain similar or more than their condition before the implementation of land acquisition. Land acquisition must not impoverish landowners.

An aspect of justice in land acquisition requires control in protecting and preserving, as well as controlling the full use of land for future development. ${ }^{5}$ Adverse matters need to be taken into account in land use planning, so it does not become a predator for the community and dogmatism is not permitted in the use of land for public interest.

Normatively, the definition of restitution in the Land Acquisition Acts mentions that "Restitution is an appropriate and fair restitution to the parties entitled to the land acquisition process." While, in Article 1246 of the Civil Code, the elements of restitution include: cost, damages, and interest. Purwahid Patrik further elaborates the elements of loss, namely actual losses (damnum emergens) i.e. cost and losses, benefits not obtained (lucrum cessans) i.e interest. The loss is sometimes only a loss suffered, but sometimes includes both elements. $^{7}$

In Indonesia, the reality of land acquisition arrangements as analyzed by the researcher is still laden with injustices. This can be seen in several legal substances in legislation relating to land acquisition. The first, the current valuation system for restitution is only based on the valuation of the object at the time of the land

\footnotetext{
${ }^{1}$ Tanya, B. L. (2006). Teori Hukum, Strategi Tertib manusia Lintas Ruang dan Generasi. Jakarta: CV Kita, p. iii

${ }^{2}$ Huijbers, T. (1993). Filsafat Hukum dalam Lintasan Sejarah. Bandung: Kanisius, p.196

3 Rawls, J. 2008). A Theory of Justice (Translated: Teori Keadilan - Dasar-Dasar Filsafat Politik untuk Mewujudkan Kesejahteraan Sosial dalam Negara. Yogyakarta: Pustaka Pelajar, p. 73

${ }^{4}$ Soumyananda D, Development and Land Acquisition in the View of Law and Economics, Munich Personal RePEc Archive, 15 July 2015

5 Raup, P.M. (1973). Achieving Land Use in Public Interest. University of Minnesota Journal. Available online at: https://ageconsearch.umn.edu/record/17826/files/ar730080.pdf

$6 \quad$ Article 1 paragraph (10) Act No. 2 of 2012 concerning the Land Acquisition for Development for Public Interest

${ }^{7}$ Patrik, P. (1994). Dasar-Dasar Hukum Perikatan (Perikatan Yang Lahir Dari Perjanjian dan Dari Undang-Undang). Bandung: Mandar Maju. p. 14.
} 
acquisition. In fact, the release of rights to land acquisition for development severs the relationship between the right owner and his land and also stops the acquisition of benefits on the land at that time and in the future. The valuation of price is done by using the price at the time of the location determination while the implementation of restitution payments can take years to cause low prices for the community. The second, in the current statutory regulations, the existing restitution system does not take into account the loss of the value of future land benefits. The unclear real value in the law causes the doubts of the appraisers to use market value, because market value is very subjective.

The third, the arrangement of non-physical restitution is very short in the statutory regulations both indicators, types and parties that should determine whether the physical restitution can be paid to the community. It causes uncertainty for both appraisal parties and those who need land. They generally consider that the determination of land that can be counted for physical restitution is not their authority, so that what happens later the appraiser chooses not to include it in the element of valuation. This is further exacerbated by the condition of law enforcement on corruption offense which has always been a scourge for all implementers so that a principle emerges that in land acquisition it is better to harm the community rather than harm the State. Last but not least, the arrangements of deliberation in the Land Acquisition Acts appear only as a formality because landowners are required to approve the price set by the appraiser and if they object they must go through court. There is no room for the public to negotiate the price set by the appraiser.

According to the researcher, justice in land acquisition for development in public interest is essentially a balance between individual and public interests so as to bring about justice for both parties, because the government as a party that requires land acquires land that will be utilized for the implementation of its functions for the livelihood of many people, while individuals get restitution for the land so that the willingness of the communities suggest that the delivery of land rights accompanied by restitution for land owned by the people is a form of community participation in development. ${ }^{1}$

\section{Impact of Non-physical Losses in Human Rights}

Indonesia is a constitutional State and the consequence of the constitutional State is that Indonesia must provide respect, protection and fulfillment of human rights. In general, the 1945 Constitution provides the protection of land rights as stipulated in Article 28 letter $h$ paragraph 4, which states that: "Every person has the right to have private property rights and these rights may not be taken arbitrarily and must be balanced with restitution." Related with legal protection to landowners, there is an obligation to provide adequate restitution for landowners. Other legal rules relating to legal protection of landowners are contained in Act No. 39 of 1999 concerning Human Rights, related to property rights (including land) as human rights and guarantees of no arbitrary deprivation of their property rights by anyone.

Protection of citizen rights to property such as land as a human right in the process of land acquisition must be protected and upheld by the State as the organizer of land acquisition for the public interest. This is done so that with the land acquisition process intended for the development of the public interest as part of the Government' sustainable development program, it can realize a social justice and welfare for all Indonesian people. $^{2}$

A universal basic principle in taking over land by the State is that: "no private property should be taken for public use without just and fair compensation" so that the land acquisition process should pay attention to the principles of justice so that it does not harm the initial owner. In this case, it is true that the Indonesian people embrace the concept of social justice. ${ }^{3}$

Human rights violations in land acquisition in various experiences were stated by Johnson A. Braun ${ }^{4}$ that the process of land acquisition by the State began and stopped at the earliest stage because the State insisted on continuing to occupy land. This is due to poor governance structures. This phenomenon continues to exist and detrimental to landowners. Resentment and agitation by the landowners related to the view of the State as a continuous predator to the nature and private property.

The impact of not providing protection for human rights in land acquisition was stated by Phan Trung Hien ${ }^{5}$ that in peace, the public interest needs to respect personal interests and vice versa. If the public interest is not

\footnotetext{
${ }^{1}$ Setiabudhi, D.O., and Palilingan, T.N. (2015). Pengadaan Tanah Bagi Pembangunan Untuk Kepentingan Umum Prosedur dan Permasalahannya. Makassar: Wiguna Media. p. 36

${ }^{2}$ Saripi, M.R. (2018). "Perlindungan Hak Asasi Manusia pada Proses Pengadaan Tanah untuk Pembangunan Kepentingan Umum.” Jurnal Lex Et Societatis, 6 (1): 42

${ }^{3}$ Surono, A. (2017). Perlindungan Hak Korban Pengadaan Tanah untuk Pembangunan Jalan Tol di Kabupaten Kendal. A Research Journal of De Jure, 17 (4): 391-409

${ }^{4}$ Braun, J.A. (2014). Compulsory Land Acqutision vis a vis the Right Property in Land a Human Rights Discource. (Dissertation) Kenyyata University School of Law, p. 37

${ }^{5}$ Hien, P.T. (2015). Striking the Right Balance Between the Public and Private Interest in Compulsory Acquisition of Land Vietnam. The Regional Centre for Social Science and Sustainable Development. 15. p.7
} 
respected, then public infrastructure, public roads, public construction can be unprotected. In this case, there will be a problem or contradiction between the flow of government (whether central or regional government) and the people (or groups of individuals). If this problem cannot be solved, it affects the community directly and politics in general. This has a direct impact on individuals in the community. In such circumstances, it is not possible for individuals to enjoy their personal interests. If the government does not respect personal interests, denying their existence, then the community will be chaotic. They no longer have the motivation to work, to improve their lives. This phenomenon might cause direct problems in the economy, society and politics.

The relationship between human rights and land acquisition in the Land Acquisition Acts is a limitation of state power in land acquisition so that it does not cause arbitrariness. Guarantees and protections in the perspective of human rights in the Land Acquisition Acts can be seen in several things, namely:

a) Open and fair process as appears in arrangement the land acquisition process from the planning stage to the implementing results conducted transparently and fairly through public consultation, socialization and deliberation.

b) Appropriate and fair restitution. If the former landowner gets compensation that makes their life better than before, before the land was taken over for public use.

c) A judicial system, the amount of restitution that is reasonable and fair, if the landowner and the government do not reach an agreement, the judicial institution that handles it.

d) The right to file an objection towards the results of inventory and identification.

e) Appointment of an independent team to valuate

f) The right to file an objection to the court regarding restitution.

The mentioned things above shows that the government will uphold human rights in land acquisition, but the reality shows that these regulations are not accompanied by clarity regarding restitution for non-physical impacts, even all forms of public consultation, deliberation, and socialization are only a formality. Various agrarian conflicts due to land acquisition have become a reality of the reduction of human rights protection in land acquisition; even in legal substance is very clearly seen, for example, by not allowing objections to values other than through court and negotiations in deliberations, not even concerning values but only forms of restitution.

Community losses in land acquisition do not only involve physical losses but also non-physical losses such as livelihood losses. Insufficient restitution or compensation to repurchase land to be used as a source of livelihood is one form of non-protection of human rights in land acquisition as well as losses due to indirect impacts suffered by the community. For example, a developer has bought and built several houses for sale and for this they have to owe it to the banks. After the location is determined, they are prohibited to continue construction and are prohibited to buying and selling while their debts in the bank continue to run along with the interest to pay. Users who initially had paid down payment demanded their money back and users who were outside the land acquisition location canceled their agreement because they did not want to buy land close to public facilities such as railroad tracks or toll roads.

Various non-physical losses suffered by the developer must clearly be considered in land acquisition, but the reality shows that the implementation of land acquisition is limited to physical restitution even for the payment of restitution for the rest of their land that is not used again after the land acquisition is very difficult to realize because the fear of the executor of the land acquisition to provide recommendations due to the scourge of law enforcement against them. Non-physical loss will be related to the condition of loss of familiarity and historical value or the nostalgia of the old place, loss of work, uncertainty in the future, loss of socio-cultural values related to land or buildings which are generally owned by customary lands or culture-laden communities and others.

The research findings as mentioned above shows that non-physical restitution in land acquisition is a problem that needs to be reviewed and given a solution so that justice and human rights in land acquisition are not lost which can keep the spirit of the land acquisition acts from reality. Observing this matter, the researcher sees that the provision of non-physical restitution needs to be clearly regulated in the Land Acquisition Acts by determining three things: First, the determination of the authority to determine the plot of land that need to be valued for non-physical losses; Second, mechanism for determining non-physical losses. The mechanism here can be done through stage of selection, verification and validation, the decision-making, and valuation/assessment; Third, determining the criteria and indicators of non-physical losses. This is done by determining the things that will be suffered by the recipient of compensation due to land acquisition such as losses due to removal costs, losses due to administrative costs, losses due to the cost of installing electricity, water and others, as well as other non-physical losses that research must be done to be able to determine it in the legislation. Hence, with a comprehensive regulation and authority, mechanisms and criteria for non-physical restitution impact will lead to legal certainty for appraisers, implementers and those who need land to make decisions without being haunted by the fear of harming the State which can cause them to have to deal with the law. 


\section{Conclusion}

The arrangement of restitution for non-physical impacts in Land Acquisition Act is still very limited. It is caused by the lack of clarity regarding the authority to determine the loss of non-physical impacts, the mechanism for determining the loss, and the absence of a regulation regarding the criteria and indicators of non-physical losses that can be valued. The limited arrangement of compensation for non-physical impacts in this law causes the implementation of land acquisition related to non-physical losses does not show justice and protection of human rights. Non-physical losses in land acquisition need to be regulated clearly and firmly in terms of authority, mechanism and categories and indicators so that they can become a reference for implementing land acquisition, those who need land and land appraisers to provide legal certainty for them in taking decisions that will not cause any legal issues and harm the country.

\section{References}

Agustina, E. (2018). The Social Function of Land Rights in Indonesia: The Basic Agrarian Law and Customary Rights by the State. Journal of Legal, Ethical and Regulatory Issues, 21(SI): 1-8.

Braun, J.A. (2014). Compulsory Land Acqutision vis a vis the Right Property in Land a Human Rights Discource. (Dissertation) Kenyyata University School of Law.

Hien, P.T. (2015). Striking the Right Balance Between the Public and Private Interest in Compulsory Acquisition of Land Vietnam. The Regional Centre for Social Science and Sustainable Development. 15.

Huijbers, T. (1993). Filsafat Hukum dalam Lintasan Sejarah. Bandung: Kanisius.

Limbong, B. (2011). Pengadaan Tanah untuk Pembangunan. Jakarta: Margaretha Pustaka.

Patrik, P. (1994). Dasar-Dasar Hukum Perikatan (Perikatan Yang Lahir Dari Perjanjian dan Dari UndangUndang). Bandung: Mandar Maju.

Raup, P.M. (1973). Achieving Land Use in Public Interest. University of Minnesota Journal. Available online at: https://ageconsearch.umn.edu/record/17826/files/ar730080.pdf

Rawls, J. 2008). A Theory of Justice (Translated: Teori Keadilan - Dasar-Dasar Filsafat Politik untuk Mewujudkan Kesejahteraan Sosial dalam Negara. Yogyakarta: Pustaka Pelajar.

Saripi, M.R. (2018). "Perlindungan Hak Asasi Manusia pada Proses Pengadaan Tanah untuk Pembangunan Kepentingan Umum.” Jurnal Lex Et Societatis, 6 (1): 42.

Setiabudhi, D.O., and Palilingan, T.N. (2015). Pengadaan Tanah Bagi Pembangunan Untuk Kepentingan Umum Prosedur dan Permasalahannya. Makassar: Wiguna Media.

Soumyananda D, Development and Land Acquisition in the View of Law and Economics, Munich Personal RePEc Archive, 15 July 2015

Surono, A. (2017). Perlindungan Hak Korban Pengadaan Tanah untuk Pembangunan Jalan Tol di Kabupaten Kendal. A Research Journal of De Jure, 17 (4): 391-409.

Syah, M.I. (2015). Pembebasan Tanah Untuk Pembangunan Kepentingan Umum. Jakarta: Permata Aksara.

Tanya, B. L. (2006). Teori Hukum, Strategi Tertib manusia Lintas Ruang dan Generasi. Jakarta: CV Kita. 